\title{
Names in German Speech
}

\section{KARL S. GUTHKE}

NE OF THE MOST COMMONLY OBSERVED LINGUISTIC PHENOMENA is that proper names penetrate into the vocabulary of a language and become regular parts of it, as shown by Professor Bryant's article in the March issue of Names. However, widespread as this feature is, it is hardly possible to tell just how many words of such origin occur in a given language because the jargon of any homogeneous social, vocational, or age group will contain certain "name words" which are not necessarily understood or used by other groups which, in their turn, have developed cants of their own. The borderline between generally accepted usage and socially limited lingo is, therefore, often hard to draw when one attempts to make a survey of words derived from names. This seems to be especially true in the case of German on account of the facility of that language for absorbing new elements into its Wortschatz.

Accordingly, the following description of present day standard German usage, while it endeavors to exclude specialist, out-moded, regional as well as cant terms, is not intended to furnish a complete list of words derived from names. Nevertheless, it is safe to say that the number of words mentioned below could hardly be increased substantially. Disregarding, then, absolute numerical totality, the purpose of this paper is rather to point out the basic forms and typical modifications in and through which names can work their way into the German language. Secondly, such a survey of names in the commonly used German vocubulary may be of interest on account of the light it throws on the cultural factors which had an impact in the shaping of present day speech. As a matter of course, German shares several of the terms of this class with English, French, Spanish and other languages; in most cases, these will require brief mention only unless they were originally coined in or connected with Germany. 
To be sure, for most of the words listed below there exist more or less exactly equivalent synonyms, but in any case, the name words convey a certain stylistic quality, which, however, cannot be discussed within the scope of this study except in the most unusual instances.

1. The most unlimited class of name words are certain fixed compounds, set phrases, consisting of a name and a noun modified by it. A considerable number of them refers to antiquity and its cultural heritage. All Germans are familiar with the following phrases, some of which are also familiar to English speaking peoples: Augiasstall (Augean stable); Pyrrhussieg (Pyrrhic victory); Stentorstimme (stentorian voice); Ariadnefaden (Ariadne's thread); Achillesferse (Achilles' heel); Nassoshemd (Nassos shirt); Tantalusqualen (Tantalus' torments); Prokrustesbett (Procrustes bed); Sirenengesang (sirens' song); Damoklesschwert (Damocles' sword); Kassandraruf (Cassandra's warning); Sisyphusarbeit (Sisyphus' labor); Ödipuskomplex; Thespiskarren (Thespis cart); Danaergeschenk (Danaän gift); etc. The original specific meaning has been expanded and generalized in all of these and similar compounds. A second group in this class alludes to Biblical persons: Petrijünger (fishermen); Hiobsbotschaft ("Job's message," i.e. bad news); Uriasbrief (Uria's letter); Pilatusfrage (Pilate's question, namely: "What is truth ?"); etc. Another group, which is virtually unlimited, refers to science: LaueDiagramm (Max von Laue); Bunsenbrenner (Bunsen burner, Robert Bunsen); Dieselmotor, Kruppstahl (Krupp steel. That the German youth was or was supposed to be "hart wie Kruppstahl" - 'hard as Krupp steel" - was a proverbial phrase during the last war); Nissenhütte (Quonset hut, named after the designer).

New name words have mushroomed every year, especially in the field of fashion novelties. Very familiar among the most recent ones are the Windsorknoten (Windsor knot); Kentkragen (Kent collar); Louis Trenker-Cordhose (very narrow cord trousers); and the Monacohemd (Monaco shirt). Litfaßsäule (advertising pillar) was coined after the Berlin printer and publisher Ernst Litfaß, who obtained permission to set up 150 such advertisement pillars in 1854. Gretchenfrage (Gretchen question, i.e. "Wie hast du's mit der Religion," - "What do you think about religion" from Goethes Faust) is quite frequently heard and read. Likewise, Goethe's Gretchen is responsible for the fairly recent neologism Gretchenfrisur (Gretchen coiffure). 


\section{Karl S. Guthke}

2. The influence of historical and literary interests can be seen in a series of familiar proverbs and quotations which contain names: among them are: Den Rubicon überschreiten (to cross the Rubicon); Eulen nach Athen tragen (to carry owls to Athens; that is to carry coals to Newcastle), Gang nach Canossa (journey of penitence); Paris ist eine Messe wert (Paris is worth a mass); sieh' Neapel und stirb (see Naples and die); Ei des Columbus (egg of Columbus); der Dank vom Hause Habsburg (thanks of the house of Habsburg; that is: ingratitude); von Pontius zu Pilatus laufen (to run from Pontius to Pilatus; that is, to go on useless errands); etwas geht aus wie das Hornberger Schießen (something ends like the Hornberg shooting; that is: if something fails because of too much preparation); es führen viele Wege nach Rom (there are many roads to Rome); but es führt kein anderer Weg nach Küßnacht (there is no other way to Küßnacht, from Schiller's Wilhelm Tell); ich kenne meine Pappenheimer (Schiller, Wallenstein, "I know my Pappenheimers") is used in somewhat condescending ironic criticism. In each of these phrases the names have naturally adopted a widened, generalized meaning. This is also true of the phrase Das ist mir Hekuba, which is frequently used in learned and would-be learned circles and which is synonymous with Das ist mir egal, gleichgültig, or, very colloquially, Gottlieb Schulze ("That does not make any difference to me"). It alludes, of course, to Hamlet's question: "What's Hecuba to him ?" (Hamlet, Act II).

3. Not infrequently, adjectives derived from names occur in certain set phrases, such as sokratische Ironie, gordischer Knoten (Gordian knot); trojanisches Pferd (Trojan horse); augusteisches Zeitalter (Augustan age); Hippokratische Züge (Hippocratic face); bengalisches Feuer (Bengal fire); kopernikanische Wendung (Copernican turn, meaning is limited to the philosophy of cognition of Kant, who coined the term); homerisches Gelächter (homeric laughter); herkulische Gewalt (herculean strength); salomonisches Urteil (judgment of Salomon: a wise decision); kastalischer Quell (castalian fountain, symbol of poetic inspiration, named after the nymph at the holy fountain at Parnassus). A böhmisches Dorf (Bohemian village) is anything that one does not understand or know. This phrase is supposed to have its origin in the fact that Czech place names sounded unintelligible and strange to the neighboring Germans. A potemkinsches Dorf, on the other hand, is any splendid sham or 
show intended to hide some miserable and shabby reality. This idiom immortalizes the trick of Gregor Alexandrovich Potemkin, a high ranking favorite at the Russian court, who on an inspection tour tried to impress Empress Catharina II by sham "villages" rapidly constructed out of odds and ends.

4. A name must enjoy a considerable familiarity with speakers of most social groups before it can adopt verb form, for in German the verb seems to be the class of words that has the strongest conservative force against the intrusion of names (and other neologisms, of course) into the language. To be sure, it is easy and a common practice to coin new words such as hebbeln, verganghofern (Herbert Cysarz), behannibalen (A. W. Schlegel) or sternisieren (early Romanticism), lessingisieren (Friedrich Schlegel), homerisieren (Herder), herderisieren, bürgerisieren, and schillerisieren (all used by Gundolf), but none of the last mentioned type has survived, except anakreontisieren, shakespearisieren, pasteurisieren (Louis Pasteur), and sokratisieren (a method of instruction by conversation and suggestive questioning, practised by the eighteenth century philanthropist school of educators, especially Basedow in his famous educational institution at Dessau). Other verbs are lynchen, mäandern, röntgen (to x-ray, named after the discoverer Wilhelm Conrad Röntgen), lumbecken (to bind books by use of glue instead of yarn, and by putting single pages together instead of sheets.) Becircen is used by teenagers mostly in the meaning of "to induce, to persuade." (Circe, of course, is the magician who seduced and transformed Ulysses' companions into animals.) Few native speakers are aware nowadays that verbalhornen (to "improve" a writing for the worse) is derived from Johann Balhorn, a Lübeck printer who put out the Lübische Stadtrecht in 1586 in a revised form which did not improve the text; to be sure, this was a common practice at that time, but only Balhorn's name happens to have become associated with it.

5. The largest group of words derived from names consists of nouns, as one would naturally expect. They can either be identical in form with the names, or take one of a very limited number of nominal suffixes, all of which occur in the words mentioned below. Examples of the latter possibility are: Robinsonade, Jeremiade (any long-winded complaint, named after Jeremiah's complaints); Münchhausiade (an unbelievable tale or adventure similar to those told by the fictitious Baron von Münchhausen and first published 


\section{Karl S. Guthke}

by R. E. Raspe). A Köpenickiade is a swindling affair resembling the one of Wilhelm Voigt of Köpenick (near Berlin), who, disguised in a captain's uniform, robbed the municipal cashier's office. This incident was treated in literature by Wilhelm Schäfer and Carl Zuckmayer and thus became widely known. Another category of name words ends in -ist or -ismus: Sadist, Sadismus (Marquis de Sade); Masochist (named after the Austrian author, Sacher-Masoch); Macchiavellist. Others include Simonie (sale of spiritual posts, after the biblical Simon Magnus of Samaria, who approached Peter and Paul with such an intention); Sodomie (the sin of the inhabitants of Sodom); Donquichotterie (from Don Quixote); Eulenspiegelei (a prank like those of Eulenspiegel); Schildbürgerei (an action that compares in foolishness with those of the Schildbürger, the inhabitants of the city of Schilda; stories about their absurd doings were collected in the Lalebuch of 1598 and retold by K. Simrock and G. Schwab). A Philippica is, as in English, a diatribe, especially a vociferous one. The word comes from Demosthenes' orations against Philip of Macedonia, after which Cicero called his speeches against Anthony orationes philippicae, thus leading the way in the generalization of the term.

Name words in -er are quite numerous, but the most familiar English word in this group, Hamburger, is entirely unknown, although is seems to have a German connotation. An Amerikaner is a piece of pastry, so is a Berliner (a jelly-filled doughnut), but a Florentiner can either be pastry or a straw hat with broad brim and ribbons that tie under the chin. Similarly, a Helgoländer is a somewhat old-fashioned hood worn by women on the North German coast. On the other hand, an Engländer (and a Franzose) do not only denote Englishman and Frenchman, but also - a screw key or wrench. A milker and herdsman is called a Schweizer, and a Römer is a type of wine glass, possibly originally a "Roman" glass. An Epikuräer is an epicure. The three most interesting words in this group are of disputed origin and etymology. A Kalauer (pun) is sometimes supposed to come from the French word for play on words, calembour, but others connect it with Kalau, a small city in Brandenburg which used to be known for the manufacture of particularly coarse boots; accordingly, coarse play on words requiring little intellectual effort was called a Kalauer in nearby Berlin. Landauer (Landau) is derived from the city of Landau in the 
Pfalz. Strangely enough, Nassauer (a sponge, also nassauern - to sponge) is mostly regarded as a derivative of a cant expression for "free of charge." But there is a theory that this very commonly used term is connected with free board for Nassau students at the University of Göttingen.

The number of words that are entirely identical with names, without any changes except that an article is added and that the meaning is broadened, is considerably greater. As a matter of course, there are various trade and firm names which would require our attention in this context if we attempted to give a complete list of words derived from names; they are above all terms for wines, automobiles, planes, fruits, cheeses, vegetables, cigars, cigarettes, clothes, musical instruments, etc. Also, international measuring units, such as Watt, Angström, Volt, Ampere, Fahrenheit, Réaumur, and others should be mentioned in this connection, and likewise generic names for nations: John Bull, Uncle Sam, Iwan, Marianne (France), Michel (Germany).

As for the less international words, let us consider given names first. Minna is a woman servant, a Gretchen a shy, chaste and inexperienced girl, while a Veronika is a flirtatious dissolute young woman (mostly used for those girls who appear in the vicinity of military baracks). A protector of a prostitute is called a Louis, but this can, more generally, also mean any man of dubious morals and behavior. An Oscar is the film trophy just as in English. A picklock is referred to as Dietrich. Hinz und Kunz means everybody, since Hinz (Heinrich) and Kunz (Konrad) were very frequent names in the late Middle Ages. Literature has furnished at least the following often used name words: Tartuffe (also Tartüff; Tartüfferie) a hypocrite, from Molière's comedy; Figaro - a barber, after Beaumarchais' Barbier de Seville and Mariage de Figaro, and Mozart's and Rossini's operas. A Don Juan is a lady's man and a charming seducer, while a Romeo is a more passionate lover. The Bible, too, has had a considerable influence in this respect, since one talks of a Benjamin (youngest son), a Thomas (somebody who is hard to convince), a Judas (venal traitor of a friend), a Johannes (precursor) and Saulus und Paulus ("aus dem Saulus ist ein Paulus geworden") to denote any abrupt and absolute change of attitude.

Other familiar words referring to the Biblical account are Goliath, Babel (a place of confusion and sinful disorder), Sodom und Go- 
morrha (a place of destruction). Philister (philistine) is interesting because its figurative meaning seems to have originated in Germany, in Jena to be quite exact. In a quarrel of the students with the city about 1690 one young scholar was killed, and parson Götze is said to have delivered a funeral sermon on Judges 16, $9 \mathrm{ff}$.: "Philister über dir, Samson." After this incident, all non-academic persons were called Philister by the students, and about a century later the meaning was expanded to include narrow-minded bourgeois mentality in general. Naturally, hardly less names from classical antiquity have found their way into the language of today: Krösus a rich man, after the last Lydian King, sixth century B.C., who was notorious for his riches; Mentor - a teacher, "governor," educator, paternal friend, from Telemach's teacher, Mentor; Xanthippe a cantankerous, capricious bad wife, from Socrates' wife, about whom several anecdotes were circulated to set off her husband's moderation and self-control; Circe - a flirtatious, seducing woman; Lucullus - a gourmet or epicure, after Lucius Licinius Lucullus, Roman commander-in-chief who became famous on account of his sumptuous banquets: Cicerone is a facetious term for a talkative guide (Cicero); it is sometimes used as a title for travel books: Jacob Burckhardt, e.g., called his guide to the works of art in Italy Cicerone (1855). Pegasus is, of course, the symbol of poetic inspiration. A Megäre is an obnoxious woman, named after one of the Erinyes. Castor und Pollux designate close friends, and one is zwischen Szilla und Charybdis if one is in a serious dilemma.

A few more examples will illustrate the various way by which names became nouns. Many designate certain types of persons: Quisling - a high traitor and collaborator with a foreign power (Vidkun Quisling, Norwegian politician who became head of the Norwegian government in 1942 after the invasion of the Germans with whom he had collaborated).

Eckermann - "Boswell," biographer, friend, and partner in conversations with a distinguished personality (Johann Peter Eckermann, Goethe's friend and author of Gespräche mit Goethe).

Lieschen Müller - sometimes: - und Tante Frieda) - a naive inexperienced person, reflecting hopelessly primitive opinions devoid of any understanding.

Dulcinea - a humorous term for "sweetheart, mistress," after Don Quixote's ladylove, Dulcinea de Toboso. 
Seladon - a lackadaisical lover, after a character in Honoré d'Urfé's pastoral romance Astrée (1610).

Moses - a cabin boy.

Blaubart - a charming and cruel lover, after the well known figure represented by Perrault, Grétry, Tieck, Offenbach, Anatole France and others; Blue Beard.

Casanova - any adventurer and lady's man (Giovanni Giacomo Casanova, Chevalier de Seingalt, whose amourous adventures became widely known).

Kaffer, Hottentotte - terms of abuse.

Krethi und Plethi - like Hinz und Kunz, everbody, mixed society, usually a derogatory term; after King David's body-guards (2 Samuel, 8, 18), probably meaning Cretian and Philistine.

Sherlock Holmes - a particularly ingenious detective.

Liliputaner - midget, from Jonathan Swift's Gulliver's Travels. Vandalen, Wandalen - vandals (metaphoric meaning as in English).

Other words designate pieces of clothing:

Stresemann - a formal suit, presumably after the German statesman Gustav Stresemann.

Borsalino - a broad-brimmed hat.

Knickerbocker - not a nickname for New Yorkers, but the term generally used for trousers strapped below the knee.

Manchester - a velvet-like cloth, mostly used for trousers.

A few other name-words are hard to classify according to subject matter:

Zeppelin - airship, named after Ferdinand Count Zeppelin, a Württemberg officer who at the turn of the century designed the dirigible airship.

Knigge - any handbook of etiquette, after Adolph Freiherr von Knigge, who in 1788 published his popular Über den Umgang mit Menschen.

Mekka - any place of pilgrimage.

Krähwinkel - the symbolic place of narrow-minded bourgeois mentality, philistinism; ("Main Street"). There is, to be sure, a village by the name of Krähwinkel near Opladen, but this term came into use through August von Kotzebue's plays Die deutschen Kleinstädter (1803) and Des Esels Schatten oder der Prozeß in Krähwinkel (1810), where Krähwinkel is meant as a fictitious place. 


\section{Karl S. Guthke}

Pompadour - a knitting bag, and more general, a small nicely decorated hand bag, after Jeanne Antoinie Poisson, Marquise de Pompadour, King Louis XV's mistress.

Derby - Derby (as in English, after Lord Derby).

Looking back on the material presented in this survey, it becomes obvious that all the major cultural influences on Europe have left their marks on the language in the way of names changed into words: antiquity, the Bible, modern science, literature and history. Moreover, about $45 \%$ of the words occur also in English. That was to be expected. However, if one looks closer, a less foreseen circumstance emerges. Vocabulary is a strange, hazardous, even dubious road to fame and perpetuation. For one thing, in many cases the fact that a very familiar word is or contains a name has mostly dropped out of consciousness in the course of the long life-time of the word (Knickerbocker, Derby, Liliputaner, Volt, Xanthippe), or was hardly ever felt as such (Nissenhütte, lynchen). Then, it happens that the name of the wrong person is eternalized in a more or less complimentary way in a word which establishes a relation of name and meaning that is non-existent, e.g. Onanie and Guillotine, and possibly $\mathrm{Ka}$ lauer and Nassauer. Moreover, it is safe to predict that the more fancy terms such as Kentkragen and Monacohemd and others denoting fashion novelties will be short-lived. And last but not least: irony and chance have their hands in the play: e.g. the only words by which the language remembers Schiller is the Schillerlocke (a fish); Bismarck had to lend his name to the Bismarckhering, Prince Pückler to a mixed ice-cream variety and Stresemann to a suit. The obscure printers Balhorn and Litfaß are immortalized in a word, but Gutenberg is not; a Seladon is remembered, but none of, say, Dante's creations. Lucullus and Epicurus live in the vocabulary, but Marcus Aurelius and Aristotle do not. The same is true of Xanthippe and Socrates, Pompadour and Louis XV., etc., and Hamlet's thoughtful "What's Hecuba to him" is leveled down in meaning to the trivial equivalent of "Gottlieb Schulze." In short, it seems to be evident that words are not necessarily a good guide to the culture they are frequently, supposed to reflect. Vocabulary is anything but just to the great names of our civilization and anything but an accurate reflection of any cultural factors. It is a strange and fortuitous way to fame, but, as for the future, a way of virtually unlimited possibilities, if ever there was one. 